Çevik, A. ve Tosunoğlu, M. (2020). İlköğretim 2. sınıf öğrencilerinin kelime servetini zenginleştirme üzerine deneysel bir çalışma. Ana Dili Eğitimi Dergisi, 8(4), 1534-1551.

Ana Dili Eğitimi Dergisi
Journal of Mother Tongue Education
www.anadiliegitimi.com
Geliş/Received: 10.09 .2020 Kabul/Accepted:29.10.2020
Araştırma Makalesi / Research Paper

\title{
İlköğretim 2. Sınıf Öğrencilerinin Kelime Servetini Zenginleştirme Üzerine Deneysel Bir Çalışma* ${ }^{* *}$
}

\author{
Arzu ÇEVIK ${ }^{* * *}$ \\ Mesiha TOSUNOĞLU***
}

Öz

Bu çalışma, ilköğretim ikinci sınıf öğrencilerinin deyim öğrenebileceği düşünülerek hazırlanmışır. Ana dili öğretiminde, kelime ve deyim öğretimi için çoğunlukla geleneksel yöntemler kullanılmaktadır. Geleneksel yöntemlerin dışında yöntem ve tekniklerle deyimlerin erken yaşlarda öğrenilebileceği varsayımından hareketle görseller ve tahkiyeli metinler aracılığıyla ilköğretim ikinci sınıf öğrencilerine deyim öğretme çalışmanın amacını oluşturmuştur. Bu amaçla deneysel yöntem tercih edilerek Kırıkkale ili Merkez ilçesinde rastgele seçilen bir okulun ikinci sınıf öğrencilerinden deney ve kontrol grubu oluşturulmuştur. Çalışmada programda yer alan "Dünyamız ve Uzay" teması ile alakalı 15 deyim ve "Hayvanlar"ın yer aldığı 15 deyim Metin Yurtbaşı"nın "Deyimler Sözlüğü"nden seçilmiştir. Bu deyimlerin bilinip bilinmediğini belirlemek için ön test uygulanmıştır. Ön test sonucunda öğrencilerin deyimleri bilmedikleri ortaya çıkmıştır. Bir derste beş deyim öğretileceği planlanarak 6 metin yazılmıştır. Bu metinler için uzman görüşü alınmıştır. Seçilen deyimler deney grubunda kullanılmak üzere bir uzman tarafından deyimin anlamına ve hikâyede geçtiği duruma uygun olarak resmedilmiştir. Deney grubunda görseller ve hikâyeler aracilı̆̆ ile öğretim yapılırken kontrol grubunda geleneksel yöntem izlenmiştir. Çalışma sonunda ikinci sınıf düzeyindeki öğrencilerin deyim öğrenebildiği ortaya çıkmışır. Görsellerin kullanıldığı deney grubunda öğrenme yüzdesi çok yüksektir. Bu çalışma ile kelime öğretimine başlandığı andan itibaren deyim de öğretilebileceği ortaya konmuştur. Kelime ve deyim öğretiminde kullanılan teknik ve tekrarın önemli olduğu belirlenmiştir.

Anahtar Kelimeler: Kelime, deyim, kelime öğretimi, deyim öğretimi, görsel-hikâye tekniği

\section{An Experimental Study to Enrich Primary School 2nd Grade Students' Vocabulary Abstract}

This study is prepared in line with the assumption that primary school second grade students can learn idioms. In mother tongue teaching, mostly traditional methods are used for teaching words and phrases. Based on the assumption that idioms can be learned at an early age with untraditional methods and techniques, the aim of the study is to teach idioms to second grade students through visuals and narrative texts. With this aim, experimental method was selected, and an experimental and control group was formed from the second grade students of a randomly selected school in the central district of Kırıkkale. In the study, 15 idioms related to the theme of "Our Earth and Space" and 15 idioms containing "Animals" were selected from Metin Yurtbasi's "Dictionary of Idioms". A pre-test was applied to determine whether these idioms were known or not. Findings of the pre-test revealed that the students did not know the idioms. It was planned that five idioms would be taught in one lesson and 6 texts were written. Expert opinion was taken for these texts.

\footnotetext{
${ }^{*}$ Makale yüksek lisans tezinden üretilmiştir.

${ }^{* *}$ Araştırmanın izni: MEB, 18/09/2009, B.08.4.MEM.4.71.00.02.-311/15726

${ }^{* * *}$ Dr. Öğr. Ü., Bartın Üniversitesi, Eğitim Fakültesi, Türkçe ve Sosyal Bilimler Eğitimi Bölümü, Bartın, acevik@bartin.edu.tr, ORCID: 0000-0001-9673-847X

${ }^{* * * *}$ Dr., Emekli, mtosunoglu@hotmail.com, ORCID: 0000-0002-7987-2156
} 
The selected idioms were illustrated by an expert to be used in the experimental group, in accordance with the meaning of the idiom and the situation in the story. While teaching with visuals and stories in the experimental group, a traditional method was followed in the control group. At the end of the study, it was revealed that second grade students could learn idioms. The learning percentage was very high in the experimental group in which visuals were used. According to the findings of the study, we conclude that idioms can be taught from the moment vocabulary teaching begins. It is also determined that the technique and repetition in the teaching of words and phrases are important.

Keywords: Vocabulary, idiom, vocabulary teaching, idiom teaching, picture-story technique

\section{Giriş}

Dilin temel unsuru kelimedir (Özkırımlı, 1994). Kelime, ses veya ses birliği, varlık ve kavramların karşılığı, söz, sözcük şeklinde açıklanabilir (Kantemir, 1997; Karatay, 2007; Korkmaz 1992; Kurudayıoğlu ve Karadağ, 2005; TDK Sözlük, 2020). İnsanın düşünce dünyasını saran simgeler ve onların yerini tutan kelimeler aracılığıyla sözlü ve yazılı iletişim sürecinde; düşünme, kavrama, karar verme ve tepkide bulunma gibi süreçler harekete geçmektedir (Karatay, 2007). Bu süreçler bireyin öğrenme yaşantısı ile bellekte depolanan kelime birikimini oluşturmaktadır (Özbay ve Melanlığlu, 2008). Kelime birikimi kavramını karşılayan terim olarak kelime hazinesi, kelime serveti, sözcük dağarcı̆̆ı gibi terimler kullanılmaktadır (Karadağ, 2018). Genellikle dildeki kelimeler, kelime grupları ve deyimler vb. oluşturduğu birimlerin tamamına gönderme yapılırken kullanılan bir kavramdır (Demirekin, 2017). Kelime serveti "ifade edici" ve "alıcı" olmak üzere iki grup altında toplanmakta anlama ve anlatmada kullanılan kelimelerin zihinde ayrı ayrı depolandığı sonucu ortaya çıkmaktadır (Karadağ, 2018; Aksan, 2004; Akyol, 1997; Kurudayıoğlu ve Karadağ, 2005). Birey aktif olarak kullanmadığı birçok kelimeyi de tanımakta ve anlamlandırmaktadır. Bu durum mecaz ya da çok anlamlı kelimeler için de geçerli olmaktadır. Gerçek anlamından farklı bir anlam taşıyan ve çekici bir anlatım özelliğine sahip olan kelime veya kelime grubu olan deyimlerin ortaya çıkışı tam olarak açıklanamasa da anlamı herkesçe bilinmektedir (Aksan, 2005; Korkmaz, 2007).

Örgün eğitime başlayıncaya kadar edinim şeklinde kazanılan ve geliştirilen dil, okulda düzenli ve planlı bir öğretimle zenginleştirilmektedir. Özellikle ilkokul ve ortaokul seviyesindeki Türkçe derslerinde dilin dört temel becerisinin eşit düzeyde geliştirilip zenginleştirilmesi amaçlanmaktadır. Programlı ve planlı bu çalışmalarda amaçlardan biri de kelime servetini artırmaktır. Ancak bu seviyedeki öğretim sürecinde kelime öğretiminin sistemli ve planlı yapıldığını söylemek mümkün değildir. Hatta bu konuyla ilgili ihmaller olduğu da düşünülmektedir; dil öğretiminde, kelime öğretimine verilen önem oldukça azdır (Erkan, 1999, s. 55). Çünkü hangi kelimenin hangi sınıflarda öğretileceği konusunda sıkıntılar mevcuttur. Tosunoğlu'na (1998) göre, ülkemizde dil konusunda yapılan araştırmaların çoğu, dilin belirli seviyelerde nasıl kullanıldığı ve kazanıldığıyla ilgilidir. Bu araştırmaların çoğu temel kelime servetinin tespitine katkıda bulunmaktadır.

Kelime servetinin artırılması için kelimelerin ve kelime gruplarının anlamları esas alınıp öğrencilerin algılama düzeylerine bağıı olarak bir öğretim planlaması yapılmalıdır. Karatay (2007), kelime servetinin geliştirilmesi için eğitim ve öğretimde kullanılacak araç-gerecin iyi tasarlanarak hazırlanması gerektiğini belirtmektedir. Ayrıca Okur ve Dağtaş (2014), Türkçe çalışma kitaplarında kelime öğretimi etkinlikleri yetersiz olduğunu ve etkinliklerin sistemli bir çalışmanın ürünü olmadığını bulgulamışlardır. (Akyüz-Aru, 2013; Başoğlu, Kaplan ve Okur, 2014; Gür, Coşkun ve Sağlam, 2013; Mangır, 2012; Pehlivan, 2003). Kelime öğretimi etkinlikleri ise çoğunlukla geleneksel yönteme göre düzenlenmiştir. Üstelik bu kelimeler belli bir listeden seçilmedikleri için gelişigüzel öğretim söz konusudur (Okur ve Dağtaş, 2014). Kelime öğretiminde sözlük kullandırmak dışında başka bir öğretme yolunun izlenmediği bu kitaplarda kelimelerin de sadece metindeki anlamını öğretmek esas alınmaktadır. Illköğretimin birinci kademesinde sadece kelimelerin öğretilmesi de yetersizliklerden biridir. Deyimler, atasözleri, kalıplaşmış sözler, benzetmeler, mecaz anlamlı kullanımlar, kavramlar vb. kelime servetini zenginleştirme çalışmalarında ele alınmadığından bilinçli bir dil gelişiminden söz etmek imkânsızdır. İlköğretimin ikinci kademesinde de aynı durum söz konusudur. İkinci kademe Türkçe ders kitaplarında deyimlerin öğretimine bakıldığında kitapların geleneksel yöntemi kullandığı görülmüştür. 
Öğretmenlerin de daha çok geleneksel yöntem ile deyim öğretimi yaptıkları bilinmektedir. Türkçe derslerinde dilin zenginliği olan deyimlerin öğretimine yeterince yer verilmemektedir. İlköğretimin birinci kademesinde deyim öğretiminin kelime servetini zenginleştirme çalışmaları içerisinde yer almaması, çocuk gelişim özellikleri arasında soyut öğrenmelere hazır olmadıkları fikridir. Ancak, Örge (2003), yaptığı çalışmada deyimlerin görseller ile ilköğretim beşinci sınıftan itibaren öğretilebileceği ortaya konmuştur. Ayrıca Baş’a (2006) tahkiyeli türlerin kelime hazineleri, deyim, atasözü ve ikileme kullandıklarını belirlemiştir. Baş (2005), bir başka çalışmasında tarafından çocuk dergileri üzerine yapılan araştırmada, 5 farklı çocuk dergisinde bulunan temel kelime hazinesi, deyim ve atasözleri tespit etmiştir.

Dilin zenginliği olan deyimler günlük yaşamda çocuğun karşısına çıkmakta, çocuk kelime anlamına bakmadan kulak dolgunluğu ile servetine kattığı deyimleri günlük yaşamında kullanmaktadır. Önemli bir eksik deyim öğretiminin sistemli bir şekilde gerçekleştirilmiyor olmasıdır. Çocukları dilin bu zenginliğinden mahrum etmek yanlış olacaktır. Oysa kelime servetinin zenginliği çok önemlidir. Erken yaşta kazanılan kelime ve kelime gruplarının unutulmadığı ve işler bir şekilde kullanıldığı, aktif kelime hazinesinde yer aldığı, araştırmalarla ortaya konmuştur. Kelime hazinesinin zenginliği ile okuma başarısı arasında olumlu yönde bir ilişki vardır. Zengin kelime hazinesi olanlar, kelime öğrenmede farklı stratejileri de kullanmaktadırlar. Yetersiz kelime hazinesi olanlar gittikçe güçleşen metinleri okuyamamaktadırlar. Dolayısıyla kelime hazineleri nitel ve nicelik olarak sınırlı kalmaya devam etmektedir (Akyol ve Temur, 2014). Dil öğretiminin temel amacı, bireyin temel dil becerilerinde etkili bir şekilde kullanabilmesini sağlamaktır. Bu amacı gerçekleştirmek için bireyin zengin bir kelime birikimine sahip olması gerekmektedir (Doğan, 2014; Memiş, 2018; Zorpuzan, 2019). Bu konuda da önemli çalışmalar yapılmaktadır. Kurudayıoğlu ve Karadağ (2005), Karatay (2007), Özbay ve Melanlıoğlu (2008), Doğan (2014), Biçer ve Polatcan (2015) vb. şeklinde örnek verebiliriz. Kelime servetini zenginleştirmek kelimeleri öğretimine önem verilmesiyle sağlanacaktır. Kelime servetinin zenginleşmesi ile okuma becerisi de gelişecektir. Çağın bilimsel teknolojik gelişmeleriyle her an etkileşen çocuklar, bu etkileşimin bir neticesi olarak eskiye göre daha erken yaşlarda zihinsel ve fiziksel olarak gelişmektedirler. Soyut ve mecaz kavramları da oldukça erken yaşlarda kavrayabilmektedirler. Çocukların günlük hayatta duyarak edindikleri birçok mecaz anlamı olan kelime ve deyim, pasif kelime servetleri içinde yer almaktadır. Bunları üretici kelime servetine dönüştürmek planlı ve programlı öğretim çalışmalarını gerekli kılar. Ancak mecaz anlamın ve deyimlerin hangi sınıfta öğretileceği bilimsel araştırmalara dayanmalıdır. Okuma sürecinde öğrencinin kelimeleri tanıması oldukça önemlidir. Kelime tanıma; öğrencinin zihinsel sözlüğünü kullanarak kelimenin anlamını belirlemesi sonucu gerçekleşmektedir. Kelimenin anlamı belirlenirken ön bilgiler kullanılmaktadır. Kelimelerin doğru tanınması; cümlelerin, paragrafların ve giderek bütün metnin yanlış anlaşıımasına neden olmaktadır. Bu nedenle kelime çalışmalarına gereken önem verilmeli ve öğrencilerin söz varlığı geliştirilmelidir (MEB, 2005, s. 21) şeklinde ifade edilmiştir. 2005'ten sonraki programlarla birlikte kelime öğretimi çeşitli öğretim yöntemleri kullanılarak zenginleştirildi. Yenilenen programda kelime öğretiminde etkinlik ağırlıklı bir öğretim öngörülmüş, kitaplara yansıması beklenmiştir. Çok hızlı değişen ve gelişen bir dünyada bilginin her gün kendini yenilediğini unutmamak gerekir. Kelime öğretiminin de bu yeniliklere dayalı yapılması doğru olacaktır.

Kelime servetinin zenginleştirilmesi önce aile ortamında doğal olarak sonrasında ise okulda planlı bir şekilde yapılmaktadır. Gelişim özellikleri dikkate alındığında kelime öğrenimi en hızlı küçük yaşlarda olmaktadır. Bunu göz önünde bulundurarak deyimlerin küçük yaşlarda öğrenilebileceği düşünebilir. Burada en önemli dayanak çocuğun günlük yaşamda çok sık karşısına çıkan kelime ya da kelime gruplarını doğal olarak öğrenebilmesidir. Yıllar önce varlıklara ve kavramlara isim verirken bizim gibi düşünülmüş olması hoşumuza gider. İçinde bulunduğumuz durumu anlatmak veya düşüncemizi dile getirmek için en uygun sözün (deyimin veya atasözünün) önceden söylenmiş olması bize güven verir. Bütün bunlar atalarımızla aynı özellikleri paylaştığımızı; geçmişten günümüze sürüp gelen millî kültürün bizi aynı kalıplarda biçimlendirdiğini göstermektedir. Bu bağlamda dil, bir milletin bütün bireylerine aynı duygu ve düşünceleri hissettirip sevdiren ve benimseten millî bir kurumdur (Barın ve Demir, 2006, s. 4). Bir toplumun kültürel bağlarla bağlandığını ve bu bağların ortak düşünüşü ve bakış açısını oluşturduğunu ve böylece milletin oluştuğu söylenebilir. Millî bağın, ortak kültürün kişilik 
gelişimine etkisi yadsınamaz. Kültürün bir parçası olan deyimler, dil edinim sürecinde bireyin hafızasında dinleme ile yerini bulmaktadır. Bunun sistemli bir şekilde öğretilmesi için 11 yaşını beklemek çok da doğru değildir. Çünkü çocuklar kültür içinde deyimlerle karşılaşarak doğal yolla öğrenmektedir. Okul çağına gelene kadar duyarak edinilen deyimler okula başladıktan sonra öğrenilebilir. Birinci sınıf, okuma yazma becerisinin kazandıııldığı sınıf olarak düşünülüp dil öğretiminin bu aşamasından sonra kelime servetini zenginleştirmeye deyimler de katılabilir. Bu bakımdan ilköğretim ikinci sınıf, deyim öğretilmeye başlanması için uygun olabilir. Bunun sistemli bir şekilde yapılması da bu servetin zenginleşmesine önemli katkılar sağlayacaktır. Burada önemli olan doğru yöntem ve tekniği seçebilmek, sonra da uygulayabilmektir. Çocuklarda sözcük dağarcığının önemli ölçüde ve hızla zenginleştiği dönem, ilköğretim dönemidir. Özellikle ilk okuma ve yazma evresini aşan çocuklar, ilköğretim süresince günlük yaşamda kullanılması gereken sözcüklerin büyük bir bölümünü öğrenirler. Bunun dışında, bu günlük konuşma diline türlü bilgi dallarına özgü yeni sözcük ve terimleri de katar (Kavcar, Oğuzkan, ve Sever, 2004, s. 6). Ortak bir kelime serveti yaratmak kelime öğretimi ile sağlanabilir. Bu düşünceyle "ilköğretim 2. sınıf öğrencilerinin kelime servetini zenginleştirmede iki farklı öğretim tekniğinin etkisi nedir?" araştırma sorusuna cevap aranarak aşağıdaki alt problemler doğrultusunda çalışma şekillenmiştir.

- Ilköğretim ikinci sınıf öğrencilerinden deyimleri öğrenebilen ve öğrenemeyenlerin yüzdelik dilimlere dağııımları nasıldır?

- Resim-hikâye tekniğinin ilköğretim ikinci sınıf öğrencilerinden deyimleri öğrenebilenlerin dağılımı nasıldır?

- Geleneksel kelime öğretim teknikleri ile resim-hikâye tekniğiyle deyim öğretimi arasında başarı yönünden bir fark var mı?

- Kazandırılması hedeflenen iki ayrı deyim grubu, öğrenme başarısı yönünden bir farklılığa etken midir?

- Deney grubunun cinsiyet ve okul öncesi eğitim alma durumları, deyim öğrenmede başarıyı etkileyen faktörler midir?

\section{Araştırmanın Modeli}

\section{Yöntem}

Araştırma deneysel yöntemle yapılmıştır. Çalışmanın yürütüldüğü okul rastlantısal olarak seçilmiştir. Araştırmada "Ön-Son Kontrol Gruplu Seçkisiz Desen" kullanılmıştır. Gerçek deneysel desen modellerinden biri olan bu desen literatürde en çok karşılaşılan modellerden biridir. "Bu klasik bir modeldir. Önce denekler şans, örnekleme yoluyla seçilerek iki grup oluşturulmuştur. Sonra yine şans yöntemiyle bu gruplar deney ve kontrol grubu olarak tayin edilmiştir. Böylece gruplar deney başlamadan önce eşitlenmiş ve seçme etkisi kontrol altına alınmıştır. Deney ve kontrol gruplarını aynı gözlemci test edebileceğinden bu tür araştırmalarda araç etkisi de bir problem değildir. Ancak deneklerin deney grubundan mı yoksa kontrol grubundan mı olduklarını bilememelerinde yarar vardı" (Kaptan, 1998, s. 88).

\section{Araştırma grubu}

Araştırmanın evreni, 2009-2010 eğitim öğretim yılı Millî Eğitim Bakanlığına bağı̆ Kırıkkale ilindeki resmî ilköğretim okullarında okuyan 2. sınıf öğrencilerini kapsamaktadır. Illköğretim 2. sınıflarla yapılan bu uygulama için Kırıkkale Valiliği ve İl Millî Eğitim Müdürlüğünden gerekli izinler alındıktan sonra seçkisiz olarak seçilen Şehitler İlköğretim Okulunda çalışma yürütülmüştür. Şehitler illköğretim Okulunda yer alan 6 şube içerisinden rastgele seçilen $C$ ve $F$ şubeleri ile uygulama yapılmıştır. $C$ ve $F$ şubelerinde okuyan 64 (altmış dört) öğrenci çalışmanın örneklemini oluşturmuştur. Bu öğrenciler arasında uygulamaların hepsine katılan 50 (elli) öğrencinin verileri değerlendirmeye alınmıştır.

\section{Veri Toplama Araçları}

Uygulamaya başlanmadan önce Türkçe Öğretim Programı (1-5. Sınıflar için), Deyimler Sözlüğü, 2. sınıf ders kitapları incelenmiştir. Deneye başlamadan önce araştırmacı bu yaş grubunu tanımak 
amacıyla ön uygulama yapmıştır. Ön uygulamada öğrencilerle Türkçe dersi yapılmış, bu yaş grubu için Millî Eğitim Bakanlığının uygun gördüğü metinler ve programda yer alan etkinlikler ile ön uygulama tamamlanmıştır. Ön uygulamada edinilen izlenimler ile asıl uygulamanın yapılması için gerekli materyaller hazırlanmıştır. Deneysel çalışma ile öğretilecek deyimler Metin Yurtbaşı"nın "Deyimler Sözlüğü"nden seçilmiştir. Bir ön-test hazırlanarak öğrencilerin deyimi bilip bilmedikleri tespit edilmiştir. Tespit edilen deyimlerin tematik yaklaşıma uygun olarak bir tema içinde yer almasına özen gösterilmiştir. Bu bakımdan programda yer alan "Dünyamız ve Uzay" teması ile somutlaştırılması ve resmedilmesi daha kolay olacağı düşünülen çocukların günlük yaşamda karşılaşabileceği hayvanların kullanıldığı deyimler seçilmiştir. Kelime servetinin önemi göz önünde bulundurularak bu servete deyimlerin de katılması gerektiği düşüncesi ile araştırma gerçekleştirilip sonuçları da ortaya konulmuştur. Soyut kavramlarla, mecaz anlamlarıyla yüklü deyimlerimizin daha kolay anlaşılabilmesi için Türkçemizdeki yolların biri de onları somut sözlerle birlikte kullanmaktır. İlk sınıflarda okuyan öğrenciler bildikleri organ adlarıyla yapılan deyimleri belki daha iyi öğrenip kullanabilirler. Bu tür deyimlerde yer alan somut sözler veya organ adları ile uzun uzun anlatmaya gerek kalmaksızın, kısa bir açıklama ile daha kolay anlaşılır duruma getirebilirler (Gözaydın, 2010, s. 1149). Deyim öğretimi için uygun deyimler bu düşünce ile seçilmiştir. Öncelikle tematik yaklaşımla öğretim yapan Türkçe Öğretim Programını (1-5. Sınıflar) esas alarak Dünyamız ve Uzay teması ile alakalı deyimler seçilmiştir. İkinci grup deyimler seçilirken de somutlaştırma kolaylığına çocukların gündelik yaşamda karşılaşacağı hayvanların geçtiği deyimler olmasına özen gösterilmiştir.

Deyim öğretmek için seçilen yöntem-teknik de oldukça önemlidir. Çalışmada resim-hikâye tekniği kullanılmıştır. Resim-hikâye tekniği, bir hikâyede yer alan belli sayıdaki deyim ile bu deyimleri ifade eden resimlerin kullanılması temeline dayanmaktadır. Soyut anlamları, görsellerle somutlaştırma ve anlamlı bütün içerisinde deyimleri birbiriyle ilişkilendirip kavratmayı esas almaktadır. Öğretme, pekiştirme ve değerlendirme süreçlerinde bulmaca çözme, tamamlama vb. farklı öğretim tekniklerinin kullanıldığı bu teknik, kelime öğretimi amacıyla geliştirilmiştir. Uygulama ile bu tekniğin deyim öğretiminde de başarı sağladığı görülmüştür. Bir derste en fazla beş yeni deyimin verilmesine dikkat edilmiştir. Bu çerçevede seçilen 30 deyim 6 ayrı metne yerleştirilmiştir. Bu metinler için uzman görüşü alınmıştır. Metinlerin ikinci sınıflar için uygun olduğu yönünde görüş alındıktan sonra bir uzman tarafından deyimin anlamına ve metne uygun olarak resmedilmiştir.

Tematik yaklaşımla hazırlanan program esas alındı̆ı̆ından öğretilecek deyimlerin ilk grubunu programda yer alan "Dünyamız ve Uzay" teması ile ilgili 15 deyim oluşturmuştur: "dürbünün tersiyle bakmak, bir bardak suda fırtına koparmak, dünyanı kaç bucak olduğunu anlamak, dünyayı hiçe saymak, denizden çıkmış balığa dönmek, gözleri ufukta güneşi aramak, günleri gece olmak, gök gibi gürleyip şimşek gibi çakmak, ırmakları düze sokmak, dünyası başına dar gelmek, dünyayı tozpembe görmek, dünya penceresi, dünyadan haberi olmamak, gökte ararken yerde bulmak, dünya dünya olalı." Deyim öğretiminin ikinci grubunu bu yaş grubu çocukların hayvanlara olan ilgi ve sevgisi dikkate alınarak, televizyon, bilgisayar ve çizgi filmlerden tanıdığı "Hayvanlar"ın yer aldığı deyimler oluşturmaktadır. Bu deyimlerin resimle ifade edilebilir olmasına da dikkat edilmiştir: "fareler cirit atmak, sinek avlamak, devede kulak, öküz öldü, ortaklık ayrıldı, aralarından kara kedi geçmek, ata binmeden ayaklarını sallamak, balıklama dalmak, örümcek bağlamak, kuş kondurmak eşeğin büyüğünü ahırda unutmak, kaplumbağaya binmek, leyleğin yuvadan attığı yavru, dananın kuyruğu kopmak, keçi gibi başını sallamak, bülbül kesilmek" Bu deyimleri içeren bir metin örneği ve hazırlanan görselleri verilmiştir:

\section{BERKAY ILE DEDESI}

Berkay, sekiz yaşında çok mutlu bir çocuktu. Neşeliydi, yüzünden gülücükleri eksik olmazdı. Onu görenler, dünyayı tozpembe görmek insanı ne kadar da güzelleştiriyor, diye düşünürlerdi.

Bugün, Berkay için üzücü bir gündü. Dedesi ameliyat olacaktı. Bugünden sonra dedesinin daha çok dinlenmesi gerekecekti. Berkay ile dedesi, birlikte güzel vakit geçirirlerdi. Berkay'ın en iyi oyun arkadaşı dedesiydi. Annesi ve babası bütün gün işteydi. Berkay onlar işteyken evde dedesiyle kalırdı. Birlikte oyunlar oynar, parka giderlerdi. 
Berkay en çok parkta oyun oynamayı severdi. Artık parka gidemeyeceklerdi. Dedesi iyileşinceye kadar dışarı bile çıkamayacaklardı.

Dedesi erkenden hastaneye gitti. Berkay pencerenin önüne oturdu, dedesini beklemeye başladı. Onun için endişeleniyordu. Annesi yanına geldi ve "Deden akşama doğru gelecek, burada o kadar bekleyemezsin, istersen odanda oyna." dedi. Berkay, biraz bekledikten sonra annesinin sözünü dinleyip odasına gitti. Kitaplarını karıştırdı, oyuncaklarını düzenledi, bir süre sonra oyuna daldı.

Birden zil sesi ile irkildi. Koşarak kapıya gitti. Babasıyla dedesi gelmişlerdi. Dedesinin gözünde bant vardı. Onu gördüğüne çok sevindi. Berkay heyecanla sordu:

-Dede, nasılsın? Dedesi gülerek:

- İyiyim evlat, dünya pencereme perde çekildi, dedi.

Doktorlar, dedesinin iki gözünü de ameliyat etmişler; sonra da zarar görmesin diye bantlarla kapatmışlardı. Bu nedenle dedesi birçok zorluk yaşadı. Tabi, Berkay da... Dedesi ameliyat olduğundan beri dışarıya çıkmıyorlar, evde oturuyorlardı. Berkay'ın canı çok sıkılıyordu. Özellikle bugün, bu güneşli güzel havada evdeydiler. Berkay bugün parka gitmeyi çok istiyordu. Annesi ve babası işe gitmişlerdi, evde bir tek dedesi vardı. Berkay dedesine:

-Bugün parka gidelim mi? diye sordu. Dedesi:

Oğlum bandajlarım açıldı ama gözlerim hâlâ iyi görmüyor; dışarıya çıkmamız doğru olmaz, dedi. Dedesinin gözlerinin iyi görmemesi Berkay'ı üzdü. Berkay dedesinin bir an önce iyileşmesini istiyordu.

-Dede, ne zaman iyileşeceksin? diye sordu. Dedesi:

-Birkaç ay içinde gözlerim daha iyi görecek. O vakit istediğimiz zaman parka gidebiliriz, dedi.

Parka gidemedikleri için üzüldü; ama dedesini üzmek istemiyordu, oyuncaklarını aldı ve salonun bir köşesine çekildi. Berkay oyuncaklarıyla oynarken dünyadan haberi olmazdı. Ne kadardır oynadığının, etrafında neler olduğunun farkında değildi. Birden dedesinin onu çağırdığını duydu:

-Efendim dedeciğim, dedi. Dedesi:

-Gözlüğümü bulamadım evlat, gördün mü? diye sordu. Berkay:

-Hayır dedeciğim, sana yardım edeyim mi?

Dede torun gözlüğü aramaya koyuldular. Bütün evi aradılar; fakat bulamadılar. Her ikisi de artık bulamayacaklarını düşünüyorlardı. Dedesi:

-Bırak oğlum, akşam annene söyleriz, o bulur, dedi.

Berkay koşarak dedesinin kucağına oturdu. Dedesinin tombul yanaklarını iki eliyle sıkıştırıyor, bir yandan da o yanaklara öpücükler konduruyordu. Dedesi:

-Oğlum ellerin temiz mi? Daha yeni ameliyat oldum, mikrop kapmamam gerek, dedi.

Berkay özür dileyip ellerini yıkamak için banyoya koştu. Bir de ne görsün! Aynanın önünde dedesinin gözlüğü... Berkay çok mutlu oldu. Sevinçle "Dede!" diye bağırdı, "Gözlüğün buradaymış!" Dedesi: "Gözlüğü gökte ararken yerde bulduk." dedi. Çünkü gözlüğü her yerde aramışlardı ama banyoya bakmak akıllarına gelmemişti. Berkay gözlüğü bulduğuna çok sevindi. Kendisini bir kahraman gibi hissediyordu. Çünkü tıpkı kahramanlar gibi faydalı olmuştu. Dedesi, onun sayesinde akşama kadar zorluk yaşamayacaktı. Akşam annesi ve babası geldiğinde gözlüğü bulduğunu anlatacaktı.

Akşam babası ve annesi, Berkay'ın anlattıklarını büyük bir dikkatle dinlediler. Dedesine yardımcı olduğu için ona teşekkür ettiler. Kendisini bir kahraman gibi hissetmesini biraz abartılı buldular; ancak ona bütün gece "kahraman" diye seslendiler. Dedesi, bu konuşmaları gülerek izledi ve torununu sevindirmek için:

-Dünya dünya olalı böyle kahramanlık görmedi evlat, dedi. 
Berkay, bütün gece mutlu ve neşeli bir çocuk olarak oradan oraya zıpladı durdu. Yatağına uzandığında içinden "Hayat ne güzel!" diye geçirdi. $O$, dünyayı toz pembe görüyordu. Kocaman bir gülümseme ile uykuya daldı.
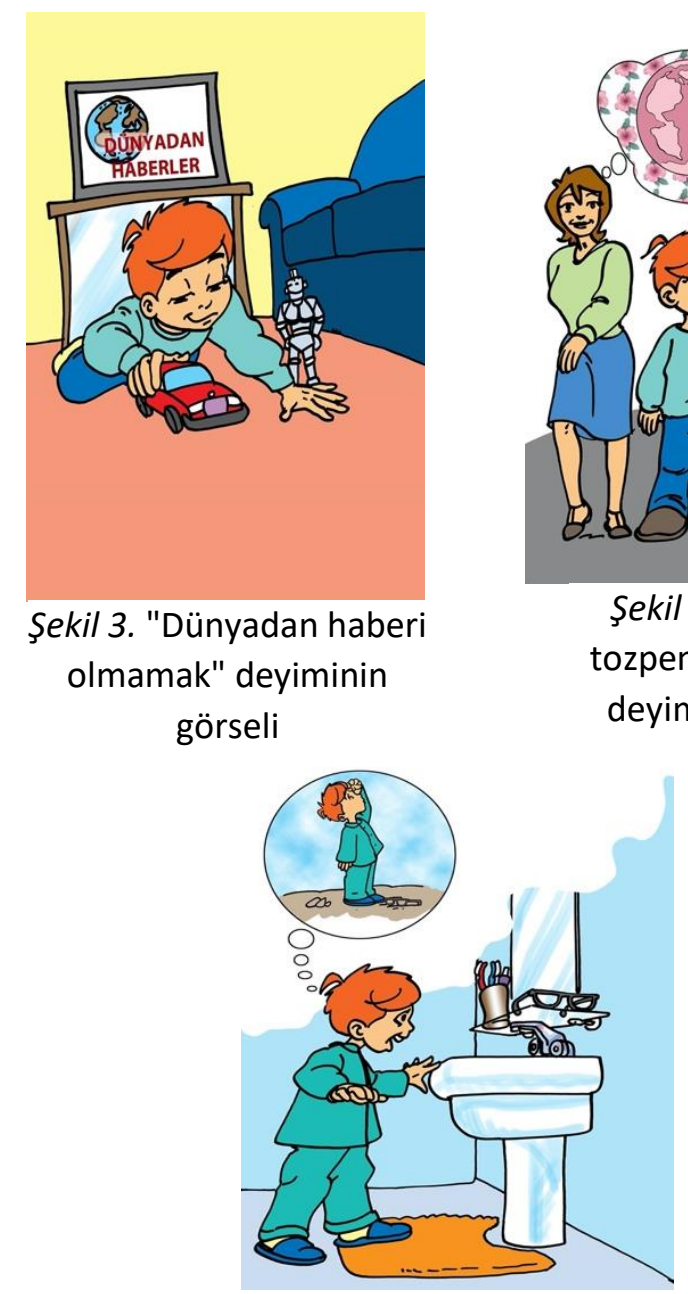

Şekil 4. "Gökte ararken yerde bulmak" deyiminin görseli

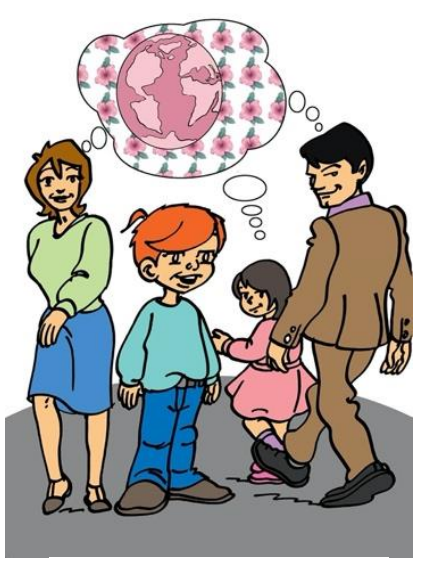

Şekil 2. "Dünyayı tozpembe görmek" deyiminin görseli

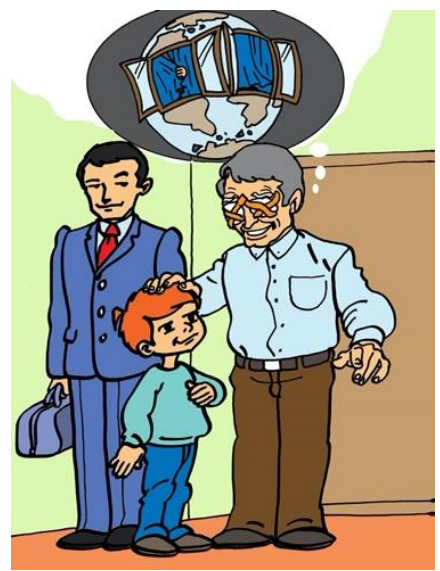

Şekil 1. "Dünya penceresi" deyiminin görseli

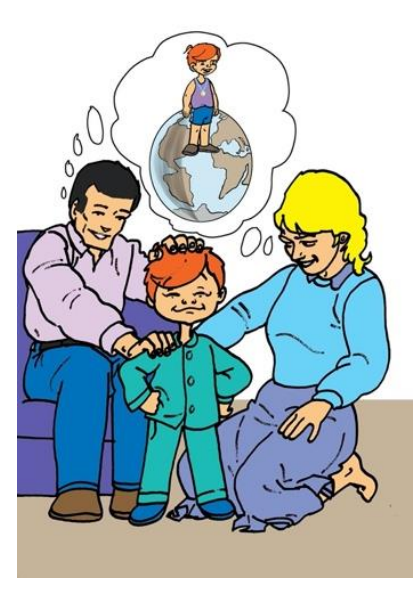

Şekil 5. "Dünya dünya olalı" deyiminin görseli

\section{İşlem / Verilerin Toplanması}

Uygulama yapmak üzere Kırıkkale ili Merkez ilçesinde bulunan Şehitler illköğretim Okulu seçilmiştir. Ailelerin gelir seviyeleri ve eğitim düzeyleri göz önüne alındığından aynı okulda yer alan iki sınıf Deney ve Kontrol grubu olarak belirlenmiştir. Deney ve kontrol grubunda farklı iki kelime öğretimi tekniği uygulanmıştır. Çalışmada ön test, ara test ve son test uygulanmıştır. Bütün testlerde üretici ve alıcı kelime hazinesi dikkate alınarak iki farklı test yapılmıştır. Testlerin sonuçları karşılaşılmıştır. Kontrol ve deney grubunda öğretim teknikleri karşılaştırıldığından aynı ölçme aracı kullanılmıştır. Bütün testler her iki grupta da aynıdır.

Araştırmanın asıl uygulaması 11 haftalık bir süre içerisinde tamamlanmıştır. Uygulama 20092010 eğitim öğretim yılının ikinci döneminde gerçekleştirmiştir. Haftada iki gün (salı ve perşembe) uygulama yapılmıştır. Eğitime verilen aralarda ya da okulun programı ile uyuşmayan günlerde araştırma bir sonraki güne aktarılarak sürdürülmüştür (çarşamba ve cuma). Uygulamada bir hafta 2 ve 3. ders saatlerinde deney grubu ile 4 ve 5 . ders saatlerinde kontrol grubu ile diğer hafta 2 ve 3 . ders saatlerinde kontrol grubu ile 4 ve 5 . ders saatlerinde deney grubu ile dönüşümlü olarak çalışma yürütülmüştür. Bu uygulamanın amacı ders saatinin etkisini aza indirmektir. Uygulama deney ve kontrol grubunda perşembe günleri 2. ve 4. ders saatlerinde değiştirilerek yürütülmüştür. 
Deneyde kullanılan resim-hikâye tekniğinin aşamaları şöyledir: "Motivasyon," Hikâyenin okunması, Resimlerin gösterilmesi, Resim-deyim ilişkisinin kullanılması, Deyimlerin anlamlarının metnin bütünlüğünden, resim-deyim ilgisinden çıkarılması, öğrencilerin deyimlerle ilgili yazılar yazması Tekrar, pekiştirme (Dramatizasyon, Resimli kartlar), Ara test, Genel tekrar, Hatırlatma, Son test. Kontrol grubuna uygulanan geleneksel yöntemin aşamaları şunlardır: "Motivasyon, Metnin (hikâyenin) okunması, Deyimlerin anlamlarının sözlükten bulunması, Deyimleri cümle içinde kullanma, Tekrar, pekiştirme (Anlamlara yönelik, açıklama kartları, Sözel hatırlatma), Ara test, Genel tekrar, hatırlatma, Son test."

\section{Verilerin Analizi}

Belirlenen deyimlerle ilgili testler deyimi öğretmeden önce ön test, öğretimin ardından ara test ve temayı içeren üç metin işlendikten sonra son test uygulanmıştır. Bütün testlerde hem sözlük bilgisi hem de cümle içerisinde uygun şekilde kullanımına yönelik sorular hazırlanmıştır. Üretici ve alıcı kelime hazinesi dikkate alınmıştır. Deyimin aktif olarak kullanılmasında tekniğin etkisi de ölçülmeye çalışılmıştır. Deyim, anlamının bilinmesi ve doğru kullanılması açısından değerlendirilmiş başarı yüzde olarak ifade edilmiştir. Araştırma verileri betimsel istatistikler ve Fisher Exact testi yardımıyla analiz edilmiştir. Her deyim için ayrı ayrı öğrenme durumları ile ilişkilendirilmiştir. $(p>0,05)$

\section{Etik Kurulu İzni}

Araştırmada MEB tarafından gerekli izinler alınarak çalışma gönüllü olan öğretmenlerin sınıflarında gerçekleştirilmiştir. Ayrıca metinler ve testleri için beş uzman görüşü alınmıştır.

Kurul adı $=$ MEB

Karar tarihi $=18 / 09 / 2009$

Belge sayı numarası= B.08.4.MEM.4.7100.02.-311/15726

\section{Bulgular}

Araştırmada, ilkokul 2 sınıf öğrencilerinin deyim öğrenme durumları ortaya konmak üzere yapılan deneysel çalışmanın bulgularına yer verilmiştir.

İlköğretim ikinci sınıf öğrencileri soyut anlam içeren deyimleri öğrenebilir mi?" birinci alt probleme ilişkin bulgu ve yorumlar

Tablo 1.

Dünyamız ve Uzay Temasındaki Deyimlerin Ön Test, Ara Test ve Son Test Bulguları

\begin{tabular}{lcccccc}
\hline & \multicolumn{2}{c}{ Ön test } & \multicolumn{2}{c}{ Ara test } & \multicolumn{2}{c}{ Son test } \\
\cline { 2 - 7 } & $\begin{array}{c}\text { Deney } \\
\text { grubu }\end{array}$ & $\begin{array}{c}\text { Kontrol } \\
\text { grubu }\end{array}$ & $\begin{array}{c}\text { Deney } \\
\text { grubu }\end{array}$ & $\begin{array}{c}\text { Kontrol } \\
\text { grubu }\end{array}$ & $\begin{array}{c}\text { Deney } \\
\text { grubu }\end{array}$ & $\begin{array}{c}\text { Kontrol } \\
\text { grubu }\end{array}$ \\
\hline Dürbünün tersiyle bakmak & - & $\% 2$ & $\% 86$ & $\% 36$ & $\% 86$ & $\% 48$ \\
Bir bardak suda fırtına koparmak & - & $\% 6$ & $\% 80$ & $\% 28$ & $\% 88$ & $\% 40$ \\
$\begin{array}{l}\text { Dünyanın kaç bucak olduğunu } \\
\text { anlamak }\end{array}$ & $\% 2$ & $\% 2$ & $\% 66$ & $\% 22$ & $\% 86$ & $\% 42$ \\
$\begin{array}{l}\text { Dünyayı hiçe saymak } \\
\text { Denizden çıkmış balığa dönmek }\end{array}$ & $\% 2$ & $\% 4$ & $\% 58$ & $\% 30$ & $\% 86$ & $\% 46$ \\
Gözleri ufukta güneşi aramak & $\% 2$ & $\% 2$ & $\% 64$ & $\% 18$ & $\% 84$ & $\% 38$ \\
Günleri gece olmak & $\% 2$ & $\% 2$ & $\% 82$ & $\% 34$ & $\% 86$ & $\% 56$ \\
Gök gibi gürleyip şimşek gibi & $\% 4$ & - & $\% 72$ & $\% 34$ & $\% 94$ & $\% 50$ \\
çakmak & & & & & & \\
Irmakları düze sokmak & $\% 10$ & $\% 4$ & $\% 74$ & $\% 28$ & $\% 86$ & $\% 38$ \\
$\begin{array}{l}\text { Dünyası başına dar gelmek } \\
\text { Dünyayı tozpembe görmek }\end{array}$ & $\% 4$ & $\% 2$ & $\% 48$ & $\% 12$ & $\% 66$ & $\% 34$ \\
Dünya penceresi & $\% 2$ & $\% 8$ & $\% 72$ & $\% 24$ & $\% 50$ & $\% 26$ \\
& $\% 4$ & $\% 4$ & $\% 88$ & $\% 26$ & $\% 84$ & $\% 30$
\end{tabular}


Illköğretim 2. Sınıf Öğrencilerinin Kelime Servetini Zenginleştirme Üzerine Deneysel Bir Çalışma

\begin{tabular}{lcccccc} 
Dünyadan haberi olmamak & $\% 2$ & $\% 8$ & $\% 76$ & $\% 26$ & $\% 84$ & $\% 30$ \\
Gökte ararken yerde bulmak & $\% 8$ & $\% 2$ & $\% 86$ & $\% 34$ & $\% 78$ & $\% 26$ \\
Dünya dünya olalı & $\% 4$ & $\% 2$ & $\% 82$ & $\% 16$ & $\% 90$ & $\% 42$ \\
Deyimlerin öğrenilme düzeyleri & $\% 3,06$ & $\% 3,2$ & $\% 73,8$ & $\% 27,6$ & $\% 82,26$ & $\% 39,73$ \\
\hline
\end{tabular}

Bu deyimlerin her iki grup içinde ön test sonuçları deney grubu için \%3,06; kontrol grubu için \%3,20 şeklindedir. Her iki grubun bu deyimleri öğretimden önce bilmediği ortaya çıkmaktadır. Deyimler resim-hikâye tekniğiyle öğretildikten sonra deney grubunun öğrenme başarısı $\% 73,8$ olarak tespit edilmiştir. Geleneksel yöntemin kullanıldığı kontrol grubunda ise başarı \%27,6'da kalmıştır. Öğretimden sonra yapılan tekrarlardan her iki grup için de öğrenme yüzdesinde artış görülmüştür. Deney grubunda \%73,8 olan ara test sonucu son testte \%82,26"ya ulaşmıştır. \%8,40 oranında öğrenme yüzdesinde artı̧̧ gözlenmiştir. Kontrol grubunda \%27,60 olan öğrenme yüzdesi tekrarlar ile \%39,73"e ulaşmıştır. Bulgular, resim-hikâye tekniğiyle yapılan deyim öğretiminin geleneksel yönteme göre daha etkin ve başarılı öğrenme sağladığını; ilköğretim 2. sınıf öğrencilerinin de uygun yöntem kullanıldığı zaman deyimleri öğrenebildiklerini ortaya koymaktadır

Tablo 2.

Hayvanlar Konulu Deyimlerin Ön Test, Ara Test, Son Test Bulguları

\begin{tabular}{lcccccc}
\hline & \multicolumn{2}{c}{ Ön test } & \multicolumn{2}{c}{ Ara test } & \multicolumn{2}{c}{ Son test } \\
\cline { 2 - 6 } & $\begin{array}{c}\text { Deney } \\
\text { grubu }\end{array}$ & $\begin{array}{c}\text { Kontrol } \\
\text { grubu }\end{array}$ & $\begin{array}{c}\text { Deney } \\
\text { grubu }\end{array}$ & $\begin{array}{c}\text { Kontrol } \\
\text { grubu }\end{array}$ & $\begin{array}{c}\text { Deney } \\
\text { grubu }\end{array}$ & $\begin{array}{c}\text { Kontrol } \\
\text { grubu }\end{array}$ \\
\hline Fareler cirit atmak & - & - & $\% 94$ & $\% 60$ & $\% 98$ & $\% 34$ \\
Sinek avlamak & - & $\% 4$ & $\% 74$ & $\% 48$ & $\% 88$ & $\% 32$ \\
Devede kulak & $\% 10$ & $\% 2$ & $\% 62$ & $\% 38$ & $\% 90$ & $\% 36$ \\
Öküz öldü, ortaklık ayrıldı & $\% 6$ & $\% 6$ & $\% 56$ & $\% 12$ & $\% 94$ & $\% 22$ \\
Aralarından kara kedi geçmek & $\% 28$ & $\% 8$ & $\% 66$ & $\% 28$ & $\% 98$ & $\% 28$ \\
Ata binmeden ayaklarını sallamak & $\% 12$ & $\% 14$ & $\% 80$ & $\% 18$ & $\% 92$ & $\% 50$ \\
Balıklama dalmak & $\% 12$ & $\% 4$ & $\% 82$ & $\% 36$ & $\% 96$ & $\% 46$ \\
Örümcek bağlamak & $\% 4$ & $\% 10$ & $\% 80$ & $\% 26$ & $\% 100$ & $\% 28$ \\
Kuş kondurmak & $\% 16$ & $\% 4$ & $\% 74$ & $\% 36$ & $\% 90$ & $\% 22$ \\
Eşeğin büyüğünü ahırda unutmak & $\% 6$ & $\% 2$ & $\% 84$ & $\% 50$ & $\% 84$ & $\% 36$ \\
Kaplumbağaya binmek & $\% 8$ & $\% 6$ & $\% 92$ & $\% 22$ & $\% 92$ & $\% 30$ \\
Leyleğin yuvada attığı yavru & $\% 4$ & $\% 6$ & $\% 90$ & $\% 16$ & $\% 92$ & $\% 28$ \\
Dananın kuyruğu kopmak & $\% 10$ & $\% 6$ & $\% 90$ & $\% 18$ & $\% 88$ & $\% 34$ \\
Keçi gibi başını sallamak & $\% 12$ & $\% 2$ & $\% 82$ & $\% 24$ & $\% 90$ & $\% 26$ \\
Bülbül kesilmek & $\% 10$ & $\% 2$ & $\% 84$ & $\% 36$ & $\% 92$ & $\% 42$ \\
Deyimlerin öğrenilme düzeyleri & $\% 9,2$ & $\% 5$ & $\% 79,33$ & $\% 31,2$ & $\% 92,26$ & $\% 32,93$ \\
\hline
\end{tabular}

Hayvanlar konulu deyimler içerisinde seçilerek öğretilen 15 deyimin ön test, ara test ve son test sonuçları Tablo-34"te verilmiştir. Bu deyimlerin her iki grup içinde ön test sonuçları deney grubu için \%9,20; kontrol grubu için \%5 şeklindedir. Her iki grubun bu deyimleri öğretimden önce bilmediği ortaya çıkmaktadır. Deyimler resim-hikâye tekniğiyle öğretildikten sonra deney grubunun öğrenme başarısı \%79,33 olarak tespit edilmiştir. Geleneksel yöntemin kullanıldığı kontrol grubunda ise \%31,2"de kalmıştır. Öğretimden sonra yapılan tekrarlardan her iki grup için de öğrenme yüzdesinde artış görülmüştür. Deney grubunda \%79,33 olan ara test sonucu son testte $\% 92,26$ "ya ulaşmıştır. $\% 12,13$ oranında öğrenme yüzdesinde artış gözlenmiştir. Kontrol grubunda \%31,2 olan öğrenme yüzdesi tekrarlar ile \%32,93"e ulaşmıştır. Bulgular, resim-hikâye tekniğiyle yapılan deyim öğretiminin geleneksel yönteme göre daha etkin ve başarılı öğrenme sağladığını; ilköğretim 2. sınıf öğrencilerinin de uygun yöntem kullanıldığı zaman deyimleri öğrenebildiklerini ortaya koymaktadır. 
“Resim-hikâye tekniğiyle ilköğretimin ikinci sınıf öğrencileri deyim öğrenebilir mi?” ikinci alt problemine dair bulgu ve yorumlar

Tablo 3

Deney Grubu Ön Test, Ara Test, Son Test Bulguları

\begin{tabular}{llll}
\hline & Ön test & Ara test & Son test \\
Dünyamı ve Uzay & $\% 3,20$ & $\% 73,8$ & $\% 82,26$ \\
Hayvanlar & $\% 9,20$ & $\% 79,33$ & $\% 92,26$ \\
Genel Ortalama & $\% 6,20$ & $\% 76,56$ & $\% 87,76$ \\
\hline
\end{tabular}

Deyimleri resim-hikâye tekniği ile öğretimi yapılan deney grubunda deyimlerin öğrenme genel oranları Tablo-3'te verilmiştir. Ön test sonuçlarına bakıldığında tüm deyimler \%6,20 oranında bilinmektedir. Deyimler resim-hikâye tekniği ile öğretimi öğretildikten sonra bu oran \%76,56 "ya yükselmiştir. \%70,36 gibi yüksek bir oranda başarı sağlanmıştır. Kelime öğretiminde tekrarın ve pekiştirmenin önemi yadsınamaz. Öğretim esnasında deyimler tekrar edilmiştir. Bu tekrardan sonra uygulanan son test sonu- cunda başarı oranının arttığı görülmektedir. Başarı \%87,76"dır. Bu artış oldukça önemlidir. Kelime ve kelime grubu öğretiminde tekrar başarıyı artırmaktadır. Uygulamalar sonunda deney grubunda \%81,56 gibi önemli bir başarı sağlanmıştır. Bu veriler ışığında resim-hikâye tekniği ile öğretim yapıldığında ilköğretim ikinci sınıf öğrencileri deyim öğrenebilmektedirler.

“Geleneksel kelime öğretim teknikleri ile resim-hikâye tekniği arasında başarı yönünden bir fark var mı?" üçüncü alt problemine ilişkin bulgu ve yorumlar

Tablo 4 .

Deney Grubu Ve Kontrol Grubu Temalara Göre Ön Test, Ara Test, Son Test Genel Başarı Oranları

\begin{tabular}{lcccccc}
\hline & \multicolumn{3}{c}{ Dünyamız ve Uzay } & \multicolumn{3}{c}{ Hayvanlar } \\
& Ön test & Ara test & Son test & Ön test & Ara test & Son test \\
Deney grubu & $\% 3,06$ & $\% 73,8$ & $\% 82,26$ & $\% 9,20$ & $\% 79,3$ & $\% 92,26$ \\
Kontrol grubu & $\% 3,20$ & $\% 27,6$ & $\% 39,73$ & $\% 5,00$ & $\% 31,2$ & $\% 32,93$ \\
\hline
\end{tabular}

Tablo 4'e göre resim-hikâye tekniği, geleneksel yönteme göre deyim öğretiminde daha başarılı sonuçlar sağlamıştır. Dünyamız ve Uzay Temasına ait deyimlerin öğretimi sürecinde ara testte geleneksel yöntemle elde edilen başarı \%27,6 iken resim- hikâye tekniğinde \%73,8"e ulaşmıştır. Hayvanlar ile ilgili deyimlerin öğretim sürecinde geleneksel yöntemle öğretimde \%31,2"lik bir başarı sağlanırken resim-hikâye tekniğiyle \%79,3"lük bir başarı yakalanmıştır. Son testlerde ise geleneksel yöntemin başarısı her iki grup deyim için de \%39,73 ile \%32,93 oranlarında gerçekleşirken resim-hikâye tekniğinin başarısı \%82,26 ile \%92,26 gibi yüksek düzeylere çıkmışır. İki yöntemin arasındaki başarı yönünden elde edilen sonuçlara göre resim hikâye yönteminin lehine\%59,33"tür. Görüldügü gibi resim-hikâye tekniği, deyim öğretiminde geleneksel yöntemden daha başarılı sonuçlara ulaştırmaktadır.

“Kazandırılması hedeflenen deyim grupları, öğrenme başarı yönünden bir farklılığa etken midir?” dördüncü alt probleme dair bulgu ve yorumlar:

Tablo 5.

Deney Grubu Ve Kontrol Grubu Temalara Göre Ön Test, Ara Test, Son Test Genel Başarı Oranları

\begin{tabular}{lcccccc}
\hline & \multicolumn{3}{c}{ Dünyamı ve Uzay } & \multicolumn{3}{c}{ Hayvanlar } \\
& Ön test & Ara test & Son test & Ön test & Ara test & Son test \\
Deney grubu & $\% 3,06$ & $\% 73,8$ & $\% 82,26$ & $\% 9,20$ & $\% 79,3$ & $\% 92,26$ \\
Kontrol grubu & $\% 3,20$ & $\% 27,6$ & $\% 39,73$ & $\% 5,00$ & $\% 31,2$ & $\% 32,93$ \\
\hline
\end{tabular}


Dünyamız ve Uzay teması ile ilgili deyimler ve hayvan adlarının bulunduğu deyimleri öğrenme yüzdeleri açısından incelendiğinde ön test sonuçlarında görüldüğü gibi hayvanların geçtiği deyimler daha çok bilinmektedir. Son test sonuçlarında deney grubunda Dünyamız ve Uzay temasıyla ilgili deyimlerin \%82,26 öğrenilme yüzdesine karşılık hayvan adlarının bulunduğu deyimlerin \%92,26 oranında öğrenildiği görülmektedir. Bu farkın öğretme sürecinde Dünyamız ve Uzay temasıyla ilgili deyimlerin önce öğretilmesinden öğrencilerin yönteme ve araştırmaya alışmasından, hayvanlara duydukları ilgiden kaynaklandığı düşünülmektedir. Her iki grup deyimin öğrenilme başarısı arasında \%10"luk bir fark oluşmuştur. Bu fark dikkate alınarak, öğrencilere öğretilmesi hedeflenen deyimlerin seçiminde onların ilgileri dikkate alınmalıdır, Şeklinde bir yorum yapılabilir.

Deney grubunun cinsiyet ve okul öncesi eğitim durumları deyim öğrenmede başarıyı etkileyen faktörler midir? beşinci alt problemine ilişkin bulgu ve yorumlara yer verilmiştir.

Cinsiyet açısından değerlendirme

Deney grubunda yer alan öğrencilerin cinsiyetlerine göre deyimleri öğrenme durumlarına ilişkin tablo aşağıda görülmektedir (Tablo 6).

Tablo 6.

Deney Grubundaki Öğrencilerin Cinsiyetlerine Göre Deyimleri Öğrenme Durumları

\begin{tabular}{|c|c|c|c|c|}
\hline & \multicolumn{2}{|r|}{ Kız } & \multicolumn{2}{|c|}{ Erkek } \\
\hline & Öğrenen & Öğrenemeyen & Öğrenen & Öğrenemeyen \\
\hline Dürbünün tersiyle bakmak & 7 & 4 & 12 & 2 \\
\hline Bir bardak suda fırtına koparmak & 10 & 1 & 13 & 1 \\
\hline Dünyanın kaç bucak olduğunu anlamak & 9 & 2 & 12 & 2 \\
\hline Dünyayı hiçe saymak & 7 & 4 & 11 & 3 \\
\hline Denizden çıkmış balığa dönmek & 10 & 1 & 13 & 1 \\
\hline Gözleri ufukta güneşi aramak & 9 & 2 & 11 & 3 \\
\hline Günleri gece olmak & 10 & 1 & 11 & 3 \\
\hline Gök gibi gürleyip şimşek gibi çakmak & 8 & 3 & 12 & 2 \\
\hline Irmakları düze sokmak & 6 & 5 & 7 & 7 \\
\hline Dünyası başına dar gelmek & 9 & 2 & 13 & 1 \\
\hline Dünyayı tozpembe görmek & 3 & 8 & 9 & 5 \\
\hline Dünya penceresi & 8 & 3 & 11 & 4 \\
\hline Dünyadan haberi olmamak & 10 & 1 & 12 & 2 \\
\hline Gökte ararken yerde bulmak & 7 & 4 & 12 & 2 \\
\hline Dünya dünya olalı & 8 & 3 & 12 & 2 \\
\hline Fareler cirit atmak & 10 & 1 & 14 & 0 \\
\hline Sinek avlamak & 10 & 1 & 12 & 2 \\
\hline Devede kulak & 7 & 4 & 8 & 6 \\
\hline Öküz öldü, ortaklık ayrıldı & 7 & 4 & 12 & 2 \\
\hline Aralarından kara kedi geçmek & 6 & 5 & 9 & 5 \\
\hline Ata binmeden ayaklarını sallamak & 6 & 5 & 10 & 4 \\
\hline Balıklama dalmak & 8 & 3 & 11 & 3 \\
\hline Örümcek bağlamak & 9 & 2 & 14 & 0 \\
\hline Kuş kondurmak & 6 & 5 & 9 & 5 \\
\hline Eşeğin büyüğünü ahırda unutmak & 7 & 4 & 10 & 4 \\
\hline Kaplumbağaya binmek & 9 & 2 & 11 & 3 \\
\hline Leyleğin yuvada attığı yavru & 7 & 4 & 12 & 2 \\
\hline Dananın kuyruğu kopmak & 6 & 5 & 11 & 3 \\
\hline Keçi gibi başını sallamak & 7 & 4 & 12 & 2 \\
\hline Bülbül kesilmek & 6 & 5 & 8 & 6 \\
\hline
\end{tabular}


Deyim öğrenmede cinsiyetin başarıyı etkileyen bir faktör olup olmadığı Fisher- Exact testi ile araştırılmış, test sonuçlarına göre cinsiyetin başarı açısından önemli bir faktör olmadığı görülmüştür (tüm deyimler için $p>0,05$ bulunmuştur).

Tablo 7.

Deney Grubundaki Öğrencilerin Okul Öncesi Eğitim Almalarına Göre Deyimleri Öğrenme Durumları

\begin{tabular}{|c|c|c|c|c|}
\hline & \multicolumn{2}{|c|}{ Okul öncesi eğitim almış } & \multicolumn{2}{|c|}{ Okul öncesi eğitim almamış } \\
\hline & Öğrenen & Öğrenemeyen & Öğrenen & Öğrenemeyen \\
\hline Dürbünün tersiyle bakmak & 17 & 4 & 2 & 2 \\
\hline Bir bardak suda fırtına koparmak & 21 & 0 & 2 & 2 \\
\hline Dünyanın kaç bucak olduğunu anlamak & 17 & 4 & 3 & 1 \\
\hline Dünyayı hiçe saymak & 15 & 6 & 3 & 1 \\
\hline Denizden çıkmış balığa dönmek & 19 & 2 & 4 & 0 \\
\hline Gözleri ufukta güneşi aramak & 19 & 2 & 2 & 2 \\
\hline Günleri gece olmak & 19 & 1 & 2 & 2 \\
\hline Gök gibi gürleyip şimşek gibi çakmak & 16 & 5 & 4 & 0 \\
\hline Irmakları düze sokmak & 10 & 11 & 3 & 1 \\
\hline Dünyası başına dar gelmek & 16 & 5 & 4 & 0 \\
\hline Dünyayı tozpembe görmek & 10 & 11 & 2 & 2 \\
\hline Dünya penceresi & 16 & 5 & 3 & 1 \\
\hline Dünyadan haberi olmamak & 19 & 2 & 3 & 1 \\
\hline Gökte ararken yerde bulmak & 17 & 4 & 2 & 2 \\
\hline Dünya dünya olalı & 16 & 5 & 4 & 0 \\
\hline Fareler cirit atmak & 20 & 1 & 4 & 0 \\
\hline Sinek avlamak & 20 & 1 & 2 & 2 \\
\hline Devede kulak & 13 & 8 & 2 & 2 \\
\hline Öküz öldü, ortaklık ayrıldı & 18 & 3 & 1 & 3 \\
\hline Aralarından kara kedi geçmek & 13 & 8 & 2 & 2 \\
\hline Ata binmeden ayaklarını sallamak & 14 & 7 & 1 & 3 \\
\hline Balıklama dalmak & 18 & 3 & 1 & 3 \\
\hline Örümcek bağlamak & 20 & 1 & 3 & 1 \\
\hline Kuş kondurmak & 14 & 7 & 1 & 3 \\
\hline Eşeğin büyüğünü ahırda unutmak & 16 & 5 & 1 & 3 \\
\hline Kaplumbağaya binmek & 17 & 4 & 3 & 1 \\
\hline Leyleğin yuvada attığı yavru & 17 & 4 & 2 & 2 \\
\hline Dananın kuyruğu kopmak & 16 & 5 & 1 & 3 \\
\hline Keçi gibi başını sallamak & 17 & 4 & 2 & 2 \\
\hline Bülbül kesilmek & 13 & 8 & 1 & 3 \\
\hline
\end{tabular}

Öğrencilerin okul öncesi eğitim alma durumlarının deyim öğrenmede başarıyı etkileyip etkilemediğini belirlemek için Fisher-Exact testi yapılmıştır. Test sonuçlarına göre okul öncesi eğitim almış olmanın yalnızca "Öküz öldü, ortaklık ayrıldı." deyimini öğrenmede bir farklılık yarattığı $(p<0,05)$, diğer deyimleri öğrenmede ise önemli bir faktör olmadığı gözlenmiştir (tüm deyimler için $p>0,05$ bulunmuştur). Sözü edilen deyim için elde edilen sonuçlar Tablo 8'de verilmiştir.

Tablo 8.

“Öküz Öldü, Ortaklık Ayrıldı" Deyimini Öğrenme Ille Okul Öncesi Eğitim Durumunun Karşılaştırılmasına iliş̧kin Fisher-Exact Test Sonuçları

\begin{tabular}{lcccccc}
\hline $\begin{array}{l}\text { Öğrenme } \\
\text { durumu }\end{array}$ & \multicolumn{2}{c}{ Okul öncesi eğitimi } & Toplam & Pearson X & sd & p \\
\cline { 2 - 4 } & Almış & Almamış & & & & \\
\hline Öğrenen & 18 & 1 & 19 & 6,79 & 1 & 0,03 \\
\hline
\end{tabular}




\begin{tabular}{lccc}
\hline Öğrenemeyen & 3 & 3 & 6 \\
Toplam & 21 & 4 & 25 \\
\hline
\end{tabular}

Tablo 8'de görüldüğüü üzere okul öncesi eğitim almış öğrenciler ile okul öncesi eğitim almamış öğrenciler arasında okul öncesi eğitim almış öğrenciler lehine anlamlı bir fark bulunmuştur. Okul öncesi eğitim almış öğrenciler "Öküz öldü, ortaklık ayrıldı." deyimini okul öncesi eğitim almamış öğrencilerden daha iyi öğrenebildiği görülmektedir.

\section{Tartışma ve Sonuç}

Resim-hikâye tekniğinin kullanıldığı deney grubunda bütün deyimlerde yüksek bir öğrenme başarısı sağlanmıştır. Geleneksel yöntemin kullanıldığı kontrol grubunda başarı yüzdesi ise oldukça düşüktür. Bu bakımdan ilköğretim ikinci sınıf öğrencilerinin kelime servetini zenginleştirmede öğretim tekniğinin oldukça etkili olduğu belirlenmiştir.

Dürbünün tersiyle bakmak" deyimi deney grubunda \%86 oranında öğrenilirken kontrol grubunda \%48 oranında öğrenilmiştir. "Bir bardak suda fırtına koparmak" deyimi deney grubunda \%88 oranın- da öğrenilirken kontrol grubunda \%40 oranında öğrenilmiştir "Dünyanın kaç bucak olduğunu anlamak" deyimi deney grubunda \%86 oranında öğrenilirken kontrol grubunda \%42 oranında öğrenilmiştir. "Dünyayı hiçe saymak" deyimi deney grubunda \%86 oranında öğrenilirken kontrol grubunda \%46 oranında öğrenilmiştir. "Denizden çıkmış balığa dönmek" deyimi deney grubunda \%86 oranında öğrenilirken kontrol grubunda \%50 oranında öğrenilmiştir. "Gözleri ufukta güneşi aramak" deyimi deney grubunda \%84 oranında öğrenilirken kontrol grubunda \%38 oranında öğrenilmiştir. "Günleri gece olmak" deyimi deney grubunda \%86 oranında öğrenilirken kontrol grubunda \%56 oranında öğrenilmiştir. "Gök gibi gürleyip şimşek gibi çakmak" deyimi deney grubunda \%94 oranında öğrenilirken kontrol grubunda \%50 oranında öğrenilmiştir. "Irmakları düze sokmak" deyimi deney grubunda \%86 oranında öğrenilirken kontrol grubunda \%38 oranında öğrenilmiştir. "Dünyası başına dar gelmek" deyimi deney grubunda \%66 oranında öğrenilirken kontrol grubunda \%34 oranında öğrenilmiştir. "Dünyayı tozpembe görmek" deyimi deney grubunda \%50 oranında öğrenilirken kontrol grubunda \%26 oranında öğrenilmiştir. "Dünya penceresi" deyimi deney grubunda \%84 oranında öğrenilirken kontrol grubunda \%30 oranında öğrenilmiştir. "Dünyadan haberi olmamak" deyimi deney grubunda \%84 oranında öğrenilirken kontrol grubunda \%30 oranında öğrenilmiştir. "Gökte ararken yerde bulmak" deyimi deney grubunda \%78 oranında öğrenilirken kontrol grubunda \%26 oranında öğrenilmiştir. "Dünya dünya olalı" deyimi deney grubunda \%90 oranında öğrenilirken kontrol grubunda \%42) oranında öğrenilmiştir. "Fareler cirit atmak" deyimi deney grubunda \%98 oranında öğrenilirken kontrol grubunda \%34 oranında öğrenilmiştir. "Sinek avlamak" deyimi deney grubunda \%88 oranında öğrenilirken kontrol grubunda \%32 oranında öğrenilmiştir. "Devede kulak" deyimi deney grubunda \%90 oranında öğrenilirken kontrol grubunda \%36 oranında öğrenilmiştir. "Öküz öldü, ortaklık ayrıldı." deyimi deney grubunda \%94 oranında öğrenilirken kontrol grubunda \%22 oranında öğrenilmiştir. "Aralarından kara kedi geçmek" deyimi deney grubunda \%98 oranında öğrenilirken kontrol grubunda \%28 oranında öğrenilmiştir. "Ata binmeden ayaklarını sallamak" deyimi deney grubunda \%92 oranında öğrenilirken kontrol grubunda \%50 oranında öğrenilmiştir. "Balıklama dalmak" deyimi deney grubunda \%96 oranında öğrenilirken kontrol grubunda \%46 oranında öğrenilmiştir. "Örümcek bağlamak" deyimi deney grubunda \%100 oranında öğrenilirken kontrol grubunda \%28 oranında öğrenilmiştir. "Kuş kondurmak" deyimi deney grubunda \%90 oranında öğrenilirken kontrol grubunda \%22 oranında öğrenilmiştir. "Eşeğin büyüğünü ahırda unutmak" deyimi deney grubunda \%84 oranında öğrenilirken kontrol grubunda \%36 oranında öğrenilmiştir. "Kaplumbağaya binmek" deyimi deney grubunda \%92 oranında öğrenilirken kontrol grubunda \%30 oranında öğrenilmiştir. "Leyleğin yuvadan attığı yavru" deyimi deney grubunda \%92 oranında öğrenilirken kontrol grubunda \%28 oranında öğrenilmiştir. "Dananın kuyruğu kopmak" deyimi deney grubunda \%88 oranında öğrenilirken kontrol grubunda \%34 oranında öğrenilmiştir. "Keçi gibi başını sallamak" deyimi deney grubunda \%90 oranında öğrenilirken kontrol grubunda \%26 oranında öğrenilmiştir. "Bülbül kesilmek" deyimi deney grubunda \%92 oranında öğrenilirken kontrol grubunda \%42 oranında öğrenilmiştir. 
ilköğretim ikinci sınıf öğrencileri soyut anlam içeren deyimleri öğrenebilir mi?

Çocuklar, küçük yaştan başlayarak yaşadıkları kültürün unsurları ile karşılaşmakta ve bunları doğal olarak öğrenmektedir. Deyimler soyut anlam içeriyor olsalar da günlük yaşamda sık karşılaşılan ve kalıp olarak öğrenilen kelime gruplarıdır. Bu neden- le deyim öğretimine kelime öğretimi ile aynı anda başlanabilir. Bu amaçla yapılan çalışmada öğrencilerin deyimleri öğrenebildikleri ortaya çıkmıştır: Resim-hikâye tekniğini kullanılan deney grubu öğrencileri, deyimleri, ortalama $\% 87,26$ oranında başarı göstererek öğrenmişlerdir. Geleneksel yöntemle öğretim yapılan kontrol grubu öğrencilerinin deyimleri öğrenme başarısı ise ortalama \%36,33"tür. Kısacası, ilköğretim ikinci sınıf öğrencileri uygun yöntem ve teknik kullanılarak yapılan öğretimle soyut anlam içeren deyimleri kolaylıkla öğrenmektedirler.

\section{Resim-hikâye tekniğiyle ilköğretimin ikinci sınıf öğrencileri deyim öğrenebilir mi?}

Resim-hikâye tekniği, bir hikâyede yer alan belli sayıdaki deyim ile bu deyimleri ifade eden resimlerin kullanılması temeline dayanmaktadır. Soyut anlamları, görsellerle somutlaştırma ve anlamlı bütün içerisinde deyimleri birbiriyle ilişkilendirip kavratmayı esas almaktadır. Öğretme, pekiştirme ve değerlendirme süreçlerinde bulmaca çözme, tamamlama vb. farklı öğretim tekniklerinin kullanıldığı bu yöntem, sözcük öğretimi amacıyla geliştirilmiş olsa da deyim ve atasözü öğretimi için de başarı sağlamıştır. Deneysel çalışmada iki farklı tema kapsamında 30 deyim öğretilmesi hedeflenmiştir. Bunlardan 28 tanesinde öğrenme başarısı \%75"in üzerindedir. Hedeflenen 30 deyimden sadece 2 tanesinde öğrencilerin daha düşük bir başarı ile öğrenme gerçekleştirdikleri belirlenmiştir: "Dünyası başına dar gelmek" deyiminin öğrenilme başarısı \%66"dır, "Dünyayı tozpembe görmek" deyiminin öğrenilme başarısı ise \% 50"dir.Öğretilmesi hedeflenen 30 deyimden 28 deyimin yüksek öğrenilme başarısı, ilköğretim ikinci sınıf öğrencilerine deyimlerin doğru teknikle öğretilebileceğini göstermektedir. Resim-hikâye tekniği ile deyim öğretimi yapılan deney grubunda genel başarı yüzdesi $\% 87,26$ "dır. Sonuç olarak "resim-hikâye tekniği" ile öğretim yapıldığında ilköğretim ikinci sınıf öğrencileri deyim öğrenebilmektedirler.

\section{Geleneksel kelime öğretim teknikleri ile resim-hikâye tekniği arasında başarı yönünden bir fark var mı?}

Illköğretim (II. Sınıf) Türkçe Dersi Öğretim Programı'nda deyim öğretimi yoktur. Gelişim özellikleri yönünden bu yaşlardaki çocukların soyut öğrenmeleri gerçekleştiremedikleri düşünülmüştür. Hâlbuki kelime öğretimi sözü edilen programda yer almış ve kelime öğretiminin sözlüklere dayandırılması istenmiştir. Kısacası illköğretim (II.Sınıf) Türkçe Dersi Öğretim Programı, kelime öğretiminde geleneksel yöntemi esas almaktadır. Çalışmada geleneksel kelime öğretimi yöntemiyle yapılan deyim öğretiminde başarı ortalaması \%33,36 olmuştur. Denenen resim-hikâye tekniğiyle deyimleri öğren- me oranı ise oldukça yüksek bir başarı sayılabilecek \%82,26"lık genel başarıya ulaşmıştır. Her iki yöntem arasında resim-hikâye tekniğinin lehine \% 48,9"luk bir fark görülmektedir. Bu farka göre "resim-hikâye tekniği", geleneksel yöntemden daha başarılı öğrenme sağlamaktadır.

Kazandırılması hedeflenen deyim grupları, öğrenme başarısı yönünden bir farklılığa sebep oldu mu?

Deneysel çalışmada iki farklı tema için on beşer deyim öğretilmiştir. Öğrencilerin "Hayvanlar"la ilgili deyimleri öğrenme oranı, "Dünyamız ve Uzay" temasına ait deyimlerin öğrenilme oranına göre daha başarılı çıkmıştır. Başarı farkı, bu yaş çocuklarının hayvanlara duydukları ilgiden ve bu deyimlerin daha somutlanabilir olmasındandır. Resim-hikâye tekniğiyle sürdürülen öğretim sonunda iki temaya ait deyim gruplarının öğrenilme başarısı arasındaki fark, \% 10"dur. Bu fark, içinde hayvan adı geçen deyimler lehinedir.

\section{Deney grubunun cinsiyet ve okul öncesi eğitim alma durumları deyim öğrenmede başarıyı etkileyen faktörler midir?}

Deney grubu öğrencilerinin \%44"ü kız, \%56"sı erkektir. Fisher-Exact testi ile sorgulandığında kız öğrenciler ile erkek öğrencilerin deyimleri öğrenme durumlarında anlamlı bir fark bulunmamıştır. 
Deney grubu öğrencilerinin \%84"ü okul öncesi eğitimi alırken \%16"sı okul öncesi eğitimi almamıştır. Fisher-Exact testi ile sorgulandığında okul öncesi eğitimi durumunun "Öküz öldü, ortaklık ayrıldı." deyimi dışında deyim öğrenmede anlamlı bir fark oluşturmadığı sonucuna ulaşımıştır. Okul öncesi eğitimi alanlar, "Öküz öldü, ortaklık ayrıldı." deyimini okul öncesi eğitim almayanlara göre anlamlı farklılıkla öğrenmişlerdir.

Öğrencilerin kelime servetini zenginleştirme içerisinde deyimler mutlaka bulunmalıdır ve deyim öğretiminde farkı öğretim yöntem-tekniklerinden yararlanılmalıdır. Deyim öğretimi açısından ilköğretim Türkçe Dersi Öğretim Programı gözden geçirilmeli ve ikinci sınıftan itibaren söz varlığını geliştirme amacının kazanımlarına deyim öğretimi de eklenmelidir

İlköğretim ikinci sınıf öğrencileri, deyim öğrenebilmektedirler. Ancak, başarıda en önemli etkenlerden biri yöntemdir. Bu noktadan hareketle farklı yöntemlerle deyim öğretilmelidir ve her düzey için hangi yöntemlerin kullanılacağı araştırılmalıdır. Kelime ve deyim öğretiminde kullanılacak yöntemlerle ilgili başka çalışmalar yapılmalıdır.

Deyimi öğretimine yer veren kitaplar, tek bir yöntem ve etkinlik örneği üzerinde yoğunlaşmamalı, farklı yöntem ve etkinliklerle deyim öğretimi gerçekleştirilmelidir. Öğretmenler de deyim öğretiminde değişik yöntemlerden yararlanma yoluna gitmelidirler.

Türkçe Öğretim Programı, deyim öğretimine ilköğretim ikinci sınıftan itibaren yer vermelidir. Sınıf seviyesi ve deyimlerin öğrenilme güçlük derecesine dikkat edilerek öğretilecek deyimler programda bir liste hâlinde gösterilmelidir. İlköğretim birinci kademe öğretmenlerine deyim öğretimi ile ilgili hizmet içi eğitim verilmelidir. Türkçe Öğretim Programı́nda deyim listelerinin yer alması konusunda çalışmalar yapılmalıdır. Illk sınıflarda öğretilen deyimler, sonraki sınıflarda düzenli olarak tekrar edilmeli, deyimlerin kelime servetine katılması sağlanmalı

\section{Kaynaklar}

Aksan, D. (2004). Türkçenin sözvarlığı. Ankara: Engin Yayınları.

Akyol, H. (1997). Kelime öğretimi. Millî Eğitim, 134, 46-47.

Akyol, H. ve Temur, T. (2014). Kelime hazinesinin geliştirilmesi. A. Kırklılıç ve H. Akyol (Ed.), ilköğretimde Türkçe öğretimi (4. Baskı) (ss. 193-229). Ankara: Pegem Akademi Yayınları.

Akyüz Aru, S. (2013). Yeni ilköğretim programına göre hazırlanan Türkçe ders kitaplarında kelime hazinesini geliştirmeye yönelik planlamanın incelenmesi. Ankara: Gazi Üniversitesi Eğitim Bilimleri Enstitüsü, Yayımlanmamış Yüksek Lisans Tezi.

Barın, E. ve Demir, C. (2006). Türk dil bilgisi 1. Ankara: Öncü Kitap.

Baş, B. (2005). 2005 yılında yayımlanmış bazı çocuk dergilerindeki söz varlığı üzerine bir değerlendirme. Hüseyin Kıran (Ed.). XIV. Eğitim Bilimleri Kongresi-Kongre Kitabı-2, Ankara: Anı Yayıncılık.

Baş, B. (2006). 1985-2005 yılları arasında çocuk edebiyatı sahasında yazılmış tahkiyeli metinlerin söz varlığı üzerine bir araştırma, Ankara: Gazi Üniversitesi, Eğitim Bilimleri Enstitüsü, Yayımlanmamış Doktora Tezi.

Baş, B. ve Karadağ, Ö. (2012). Söz varlığı üzerine yurt dışında ve Türkiye'de yapılan temel araştırmalar. Millî Eğitim, 193. 81-105.

Baş, B. ve İnan-Yıldız, F. (2015). 2. Sınıf Türkçe Ders Kitabındaki Metinlerin Okunabilirlik Açısından Incelenmesi. Mersin Üniversitesi Eğitim Fakültesi Dergisi, 11(1), 52-61.

Başoğlu, N., Kaplan, T. ve Okur, A. (2014). İlköğretim birinci kademede sözcük öğretimi ile ilgili çalışmaların incelenmesi. Ana Dili Eğitimi Dergisi, 2(4), 50-65.

Biçer, N. ve Polatcan, F. (2018). Yabancı dil olarak Türkçe öğretiminde kelime öğrenme stratejilerinin değerlendirilmesi. A. Ü. Türkiyat Araştırmaları Enstitüsü Dergisi [TAED] 54, , 811-828

Demirekin, M. (2017). Yabancı dil olarak Türkçenin anlamlandırılmasında kelime ve dil öğrenme stratejileri kullanımı. Ankara: Hacettepe Üniversitesi Türkiyat Araştırmaları Enstitüsü, Yayımlanmamış Doktora Tezi.

Doğan, Y. (2014). Yabancılara Türkçe kelime öğretiminde market broşürlerinden yararlanma. Journal of Language and Linguistic Studies, 10(1), 89-98.

Erkan, A. G. (1999). Dört temel dil becerisi üzerine. Dil Dergisi. 76, 50-63. 
Gözaydın, N. (2010), ilköğretimde soyut

ve somut kavramların öğretilmesi. Türk Dili-Dil ve Edebiyat Dergisi, 702. 1147-1152.

Gür, T., Coşkun, i., \& Sağlam, F. (2013). İlkokul 2, 3 ve 4. sınıf Türkçe ders kitapları bütüncesinin kelime hazinesini geliştirme eğitimi açısından incelenmesi, Turkish Studies, 8(1), 1561-1570.

Kantemir, E. (1997). Yazılı ve sözlü anlatım. Ankara: Engin Yayınevi.

Kaplan, M. (1982). Kültür ve dil. İstanbul: Dergâh Yayınları.

Kaptan, S. (1998). Bilimsel araştırma ve istatistik teknikleri. Ankara: Tekışık Web Ofset Tesisleri.

Karadağ, Ö. (2013). Kelime öğretimi. İstanbul: Kriter Yayınevi.

Karatay, H. (2007). Kelime öğretimi. Gazi Eğitim Fakültesi Dergisi, 27(1), 141-153.

Kavcar, C., Ferhan O. ve Sever, S. (2004). Türkçe öğretimi, Türkçe ve sınıf öğretmenleri için. Ankara: Engin Yayınları.

Korkmaz, Z. (1992). Gramer terimleri sözlüğ̈̈, Ankara: Türk Dil Kurumu Yayınları.

Korkmaz, Z. (2007). Türk dili üzerine araştırmalar-3. Ankara: Türk Dil Kurumu Yayınları.

Karadağ, Ö. (2018). Kelime öğretimi. Ankara: Kriter

Kurudayıoğlu, M. ve Karadağ, Ö. (2005). Kelime hazinesi çalışmaları acısından kelime kavramı üzerine bir değerlendirme. Gazi Eğitim Fakültesi Dergisi, 25 (2), 293-307.

MEB (2005). Illköğretim Türkçe dersi müfredat programı. Ankara: MEB Basımevi.

Memiş, M.R. (2018). Kelime hazinesi ve yabancı dilde kelime öğretimi üzerine. Turkish Studies, 13(19) 1273-1289.

Okur, A. ve Dağtaş, A. (2014). Ortaokula yönelik kelime öğretimi çalışmaları. Ana Dili Eğitimi Dergisi, 2(4), 66-84.

Örge, F. (2003). Illköğretim I. kademe beşinci sınıfta deyimlerin öğretimine ilişkin kullanılabilecek aktivitelere yönelik bir araştırma. Çanakkale: Çanakkale Onsekiz Mart Üniversitesi, Sosyal Bilimler Enstitüsü, Yayımlanmamış Yüksek Lisans Tezi.

Özbay M. ve Melanlıoğlu, D. (2008). Türkçe Eğitiminde Kelime Hazinesinin Önemi. Yüzüncü Yıl Üniversitesi Eğitim Fakültesi Dergisi, 5(1), 30-45.

Özkırımlı, A. (1994). Dil ve anlatım. Ankara: Ümit Yayıncılık.

Pehlivan, A. (2003). Türkçe ders kitaplarında sözcük dağarcığını geliştirme sorunu ve çözüm Yolları, Dil Dergisi, 122, 84-91.

TDK Güncel Türkçe Sözlük (2020). https://sozluk.gov.tr/ adresinden 06/05/2020 tarihinde erişilmiştir.

Tosunoğlu, M. (1998). ilköğretim okuluna başlayan öğrencilerin okuma-yazmayı öğrenmeden önceki kelime serveti üzerine bir araştırma. Ankara: Gazi Üniversitesi, Sosyal Bilimler Enstitüsü, Yayımlanmamış Doktora Tezi.

Yurtbaşı, M. (1996). Deyimler sözlüğü. i̇stanbul: Excellence Publising.

Zorpuzan, R. (2019). Türkçenin yabancı dil olarak öğretiminde kavram haritalarının kelime öğretimi üzerine etkisi. Bolu: Abant İzzet Baysal Üniversitesi Eğitim Bilimleri Enstitüsü, Yayımlanmamış Yüksek Lisans Tezi.

\section{Introduction}

\section{Extended Abstract}

Children of school age learn most of the words that should be used in daily life during primary education after the initial reading and writing phase. These words include new words and terms, even idioms and proverbs, specific to everyday speech and various branches of knowledge. It is necessary to know the meaning of words and word groups correctly for effective and accurate communication. The enrichment of vocabulary happens naturally in the family environment and then is done in a planned way at school. Considering the developmental characteristics, vocabulary learning happens fast at young ages. With this in mind, one might think that idioms can be learned at a young age. The most important basis here is that the child can naturally learn words or groups of words that he/she encounters very often in a daily life. Creating a common vocabulary list can be achieved through vocabulary teaching. With this motivation, following research questions are addressed:

- "What is the effect of two different teaching techniques on enriching the vocabulary of primary school second grade students?". 
- What is the distribution of primary school $2^{\text {nd }}$ grade students who can learn idioms and those who cannot?

- How is the distribution of those who can learn the idioms from the $2^{\text {nd }}$ grade primary school students of the picture-story technique?

- Is there any difference in success between traditional vocabulary teaching techniques and teaching idioms with picture-story technique?

- Are the two groups of idioms aimed to gain a factor in a difference in terms of learning success?

- Are the gender and pre-school education status of the experimental group factors affecting the success in learning idioms?

\section{Method}

This is an experimental study. The school where the study was conducted was selected randomly. "Randomly Selected Pre-Post Control Group Design" was used in the present study. The universe of the research included the $2^{\text {nd }}$ grade students who studied in Şehitler Primary School in Kırıkkale province, which was selected randomly after obtaining the necessary ethical permissions.

Thirty idioms suitable for two themes, thirty illustrations of the idioms and pre-test, interim test and post-test were used in the study.

\section{Result and Discussion}

"Did the picture story technique enhance the learning idioms of the $2^{\text {nd }}$ grade students of primary school education?" This research question was addressed. The picture-story technique is based on the use of a certain number of idioms in a story and the use of pictures expressing these idioms. It is based on concretizing abstract meanings with visuals and associating idioms with each other in a meaningful whole. The techniques of puzzle solving, completion etc. were used in teaching, reinforcement and evaluation processes. Although this method, in which different teaching techniques were used, was developed for vocabulary teaching, it also proved to be successful for teaching idioms and proverbs. In the experimental study, it was aimed to teach 30 idioms within the scope of two different themes. 28 of these idioms were successfully learned, which equals to over $75 \%$ success rate. It was determined that in only 2 of the target 30 idioms, students learned with a lower success: The learning success of the phrase "Dünyası başına dar gelmek" [his/her life becomes upside-down] was $66 \%$, and the learning success of the phrase "Dünya penceresi" [the eye] was $50 \%$. The success rate of learning 28 idioms out of 30 showed that idioms could be taught with the correct technique to the $2^{\text {nd }}$ grade primary school students. The overall success rate in the experimental group that learned idioms with the picture-story technique was $87.26 \%$. As a result, primary school $2^{\text {nd }}$ grade students could learn idioms when teaching with the "picture-story technique".

"Is there any difference between traditional vocabulary teaching techniques and picture-story technique in terms of success?" The average success rate in teaching idioms with traditional vocabulary teaching method was $33.36 \%$. With the picture-story technique, the success rate of learning idioms were calculated as $82.26 \%$, which could be interpreted as a very high success. There was a difference of $48.9 \%$ between the two methods in favor of the picture-story technique. According to this difference, "picture-story technique" was proved to be more successful than the traditional method.

"Are the two groups of idioms aimed to gain a factor in a difference in terms of learning success?" For this research question, fifteen idioms were taught for two different themes in the experimental study. The rate of learning the idioms about "Animals" was more successful than the rate of learning the idioms belonging to the "Our Earth and Space" theme. The difference in success rates could be due to the interest that children at this age had in animals and the fact that these idioms were more concrete. The difference between the learning success of the idiom groups belonging to the two themes at the end of the teaching carried out with the picture-story technique was $10 \%$. This difference was in favor of idioms in which animals were mentioned. 
"Are the gender and pre-school education status of the experimental group factors affecting success in learning idioms?" $44 \%$ of the experimental group students were girls and $56 \%$ were boys. Based on the analysis performed by the Fisher-Exact test it was concluded that there was no significant difference in learning idioms except for "Öküz öldü, ortaklık ayrıldı" [The ox is dead then the partnership is terminated] statement. Those who received pre-school education showed a significant difference for this idiom compared to those who did not receive pre-school education.

Primary school $2^{\text {nd }}$ grade students can learn idioms. Idioms are suggested to be used in enriching the vocabulary of the students, and different teaching methods-techniques are also suggested to be used in idiom teaching. From this point on, idioms should be taught with different methods, and methods to be used for each level should also be investigated. Other studies should also be conducted on different methods to be used in teaching words and phrases. 